\title{
Afterlives of an accidental masterpiece
}

\section{Karin Sanders: Bodies in the bog and the archaeological imagination. University of Chicago Press, 2009, 344 p, US\$37.50 HB}

\author{
Cathy Gere
}

Published online: 4 August 2010

(C) The Author(s) 2010. This article is published with open access at Springerlink.com

In the spring of 1950, two brothers cutting peat for their stove near the small Danish village of Tollund uncovered the body of a man buried two metres deep in the bog. The brothers assumed they were looking at a recently buried crime victim and notified the police. The police, aware that well-preserved ancient bodies were occasionally found by peat-diggers, showed up at the site with a couple of curators from the local museum. One look confirmed that this find was, indeed, no recent homicide, but a prehistoric corpse, pickled by the acidic, anaerobic conditions of the bog. A telephone call was put through to Aarhus University where the archaeologist Peter Glob was lecturing to a group of students. In a scant two hours, Glob and his students were at the site, bent over the remains of an Iron Age man. His expression was peaceful, his eyes were closed, and his chin was covered in stubble. He wore a pointed leather cap. A lump of peat was removed from the back of his neck revealing a braided leather noose around his neck. When the body was fully excavated, he was revealed to be naked except for a belt around his waist.

Since his discovery, Tollund Man, as he came to be known, has received forensic treatment as thorough as any TV crime victim. He has been scanned, X-rayed, and finger-printed. A thumbnail-sized sample was taken from his body and tested for the decay of carbon-14, establishing the time of death as 400-300 BCE. The distension of his tongue and condition of his cervical vertebrae indicated that he had been hanged by the leather noose found around his neck. The contents of his stomach were analysed, and his last meal turned out to have consisted of a gruel of barley plus seeds and grains from dozens of different herbs and plants. It is surmised that he was a human sacrifice, fed on sacred herbs, hanged, and then carefully interred in the bog as part of a religious ritual.

There have been many such finds, but Tollund Man is by far the most charismatic. Made famous by black-and-white photographs taken at the scene, he is

C. Gere $(\square)$

University of California at San Diego, 9500 Gilman Drive, La Jolla, CA 92093-0104, USA

e-mail: cgere@ucsd.edu 
a natural work of art, an accidental masterpiece, the polished darkness of his complexion reminiscent of bronze sculpture. Accidents of chemistry and pressure preserved his face in a form so recognisable as to collapse the millennia that separates his time from ours. The contrast between his serene slumber and the violence of his end, the hyper-realism of his skin-pores and stubble, the detail of the tissue creases of his fastidiously pursed lips, the beauty of his high cheekbones and his manicured hands, all amaze and fascinate. The absolute familiarity of his appearance coincides with the utter strangeness of his origins. In his leathery resignation, he looks as close to us as the 'migrant mother' photographed by Dorothea Lange in 1936, but he is an Iron Age human sacrifice-perhaps, one cannot help surmising from his peaceful expression, a willing one.

In the wake of the discovery, Peter Glob published some articles about Tollund Man and others of his ilk. After receiving hundreds of letters, many of them from children, he wrote a popular book called The Bog People, published in Danish in 1964 and in English translation in 1969. The book stands as an excellent example of popular archaeology: poetically written and full of forensic drama, it brilliantly evokes the mystery of these artefacts. As befits its genre, the narrative comes complete with a portentous opening scene in which one of the people helping to haul the body onto a cart collapses with a heart attack. Glob intones: "The bog claimed a life for a life, or, as some may prefer to think, the old gods took a modern man in place of the man from the past." The charisma of the find, the drama of the prose, and the perennial appeal of the archaeological detective story quickly catapulted Glob's book up the bestseller lists and into the canon of non-fiction classics.

In the preface to her Bodies in the bog and the archaeological imagination Karin Sanders, a scholar of Scandinavian literature at U. C. Berkeley, reminisces about reading The Bog People when it first came out, and dreaming of becoming an archaeologist. Years later, Seamus Heaney's poems on bog bodies reawakened her childhood fascination with these eerie relics. Finding that bog bodies have inspired a wide spectrum of responses, she embarked on a scholarly survey of the literary, political and artistic reception of these artefacts, from Sigmund Freud to Margaret Atwood. Bog bodies, she argues, are vanitas symbols, their uncanny preservation a paradoxical testament to the brevity of human life. Tollund Man, in particular, reminds of our fate "more forcefully than most memento mori" because, unlike traditional vanitas emblems such as the human skull, he "is not reduced to a pure cool sign, but has maintained an individuality which mirrors our own" (p. 39).

The vignettes that follow her preliminary analysis begin with some reflections on psychoanalytic interpretations of bog bodies, a chapter that displays all the strengths and weaknesses of the book. The material is a gift: here we have Jung and Freud locked in psychoanalytic competitiveness so fierce that Freud actually passes out. Jung describes the fainting spell as brought on by a muddled comment to Freud about bog corpses. With another interlocutor, Freud might have delighted in the archaeological reference and followed up on it. With Jung, he chose to interpret the macabre comment as Oedipal aggression and accused his rival of harbouring a strong death wish against him. "He was," Jung recounts, "inordinately vexed by the whole thing and during one such conversation, while we were having dinner together, he suddenly fainted" (p. 50). 
This amusing story of mutual hostility from the fathers of psychoanalysis is burdened by pages of labyrinthine argument about why Freud never developed an obsession with bog bodies commensurate with their murky suggestiveness. The author's frustration that these most Freudian of objects failed to grip Freud himself is spun into great cobwebs of psychoanalytic theory: "If Pompeii was to Freud a material manifestation of the unconscious, the bodies in the bogs became unmanageable hyper-visualizations of this unconsciousness." (p. 60). The answer to the puzzle of Freud's indifference might, in fact, be simpler. Most of the notable and photogenic examples of bog bodies that Sanders herself writes about emerged from the peat after Freud's death in 1938, and the main story of the reception of bog bodies concerns the legacy of the Holocaust. Sanders' colleagues in literature departments may find her account interesting and persuasive, but for this reviewer's taste, her insensitivity to basic facts of chronology and her preference for theory over fact make for a sometimes frustrating read.

More notable than Jung's glancing and muddled reference to bog bodies is Heinrich Himmler's invocation of 1937. Himmler saw bog bodies through the eyes of one of fascism's favourite writers, the Roman historian Gaius Tacitus. In his Germania, a compendium of second-hand accounts of the tribal laws of the German barbarians, Tacitus noted that traitors and deserters were hanged on trees, while cowards, sluggards, and unnatural prostitutes were buried in bogs, to hide the disgrace of their effeminacy. In a 1937 speech about the pestilence of homosexuality, Himmler spat: "Unfortunately we do not have it as easy as our ancestors did. They only had a few abnormal degenerates. Homosexuals, called Urnings, were drowned in swamps. The worthy professors who find these corpses in the bog are clearly not aware that in ninety-out-of-a-hundred cases they are faced with remains of a homosexual who was drowned in a swamp with his clothes and everything else" (pp. 61-62). The crackpot mixture of archaeology, mythology and eugenics out of which the Nazis cooked up an ancient pedigree for fascism is here raised to a wonderful pitch of absurdity, and this anecdote alone is worth the price of admission.

The rest of the book concerns the post-war reception of bog bodies. Tollund Man-the real bog celebrity-emerged in 1950, a mere five years after the liberation of the camps. Evidence of ancient violence perpetrated on these sacrificial victims made them ineluctably resonant with the brutal events just past. For Sanders, the apogee of the literary appropriations of bog bodies is Seamus Heaney's poems, but for me the palm goes to the 1970 novel The Erl King (Le roi des aulnes) by the French author Michel Tournier. The story concerns the 'myopic ogre' Abel Tiffauges, who witnesses the autopsy of a bog body in 1938 and is moved to tears by the professor's eulogy to prehistoric German culture. Becoming a prisoner of war of the Nazis, Tiffauges saves his skin by roaming the countryside kidnapping twins for medical experiments. A fantastically gripping read, the book represents a brilliant inversion of Himmler's fascist archaeology. All the tragic mnemonic freight of bog bodies in the years after 1945 is to be found within Tournier's novel, and if you were to read only one book on the subject, I would recommend the work of fiction over Sanders' rather ponderous monograph. 
Open Access This article is distributed under the terms of the Creative Commons Attribution Noncommercial License which permits any noncommercial use, distribution, and reproduction in any medium, provided the original author(s) and source are credited. 